\title{
Some new records of chironomids (Diptera: Chironomidae) from the Czech Republic
}

Peter Bitušík \& Katarína Trnková

\begin{abstract}
Some new records of chironomids (Diptera: Chironomidae) from the Czech Republic. - Acta Mus. Siles. Sci. Natur. 65: 143-147, 2016.

Abstract: Six chironomid species: Paraboreochlus minutissimus (Strobl, 1894), Trissopelopia longimanus (Staeger 1839), Boreoheptagyia monticola (Serra-Tosio, 1964), Cricotopus (s.str.) similis Goetghebuer 1921, Heleniella serratosioi Ringe, 1976, Krenosmittia camptophleps (Edwards, 1929), were recorded in Czech Republic for the first time. The pupal exuviae were collected in July 2009 from Otava River in the vicinity of Rejštejn village in the central part of the Bohemian Forest. The notes on known distribution and ecology of the species are presented.
\end{abstract}

Key words: Chironomidae, Podonominae, Tanypodinae, Diamesinae, Orthocladiinae, ecological notes, distribution

\section{Introduction}

Pupal exuviae sampling has proved to be an excellent tool to identify the occurrence, distribution and ecology of chironomids in various water biotopes. This method greatly contributed, among other things, to the knowledge of the regional fauna (see e.g. Bitušík 1993). Last time, Syrovátka \& Langton (2015) demonstrated again that even one sample taken from a locality can bring surprising results and this paper also proves it. During the limnological investigations of the lakes in the Bohemian Forest, one sample of pupal exuviae was taken from Otava River in the vicinity of Rejštejn village in July 28, 2009. Here we present the results of our survey.

\section{Material and methods}

Otava River originates at the confluence of two mountain streams Křemelná and Vydra in the central part of the Bohemian Forest. The sampling site was located at $590 \mathrm{~m}$ a.s.l. just about $3 \mathrm{~km}$ bellow the confluence $\left(49^{\circ} 08^{\prime} 02.2^{\prime \prime} \mathrm{N}, 13^{\circ} 30^{\prime} 02.4^{\prime \prime} \mathrm{E}\right)$. This is an unpolluted section of the Otava River with low content of nutrients, brownish water due to humic substances and preserved hydromorphology.

The current is strong and the bottom is composed largely of cobbles and boulders with considerable proportion of mosses on their surface. The width of the river was $15-20 \mathrm{~m}$ in time of sampling.

Floating chironomid material was sampled along the right shore of the stream by skimming the water surface with a hand net with telescopic handle (mesh size $250 \mu \mathrm{m}$, frame diameter $25 \mathrm{~cm}$ ). Collected material containing pupal exuviae and adults was placed into a labelled plastic bottle and preserved with $75 \%$ ethanol. Sorted exuviae were mounted to microscopic slides and identified using Langton (1991) and Langton \& Visser (2003). Nomenclature and distribution follow Sæther \& Spies (2013).

All specimens were collected and identified by the authors, and the material is deposited in the collection of the Dept. of Biology and Ecology, Faculty of Science, Matthias Belius University in Banská Bystrica.

\section{Survey of species}

A total of 286 pupal exuviae and 7 males were identified, mostly at species level. The diverse chironomid assemblage consisted of 36 taxa/ species: Paraboreochlus minutissimus (Strobl, 1894), Trissopelopia longimanus (Staeger 1839), Thienemannimyia geijskesi (Goetghebuer 1934), Nilotanypus dubius (Meigen, 1804), Boreoheptagyia monticola (SerraTosio, 1964), Potthastia cf. gaedii (Meigen, 1838), Cardiocladius capucinus (Zetterstedt, 1850), Corynoneura celtica Edwards, 1924, Corynoneura Pe4 Langton 1991, Cricotopus 
(s.str.) tremulus (Linnaeus 1758), C. (s.str.) similis Goetghebuer 1921, C. (s.str.) fuscus (Kieffer 1909), Eukiefferiella coerulescens (Kieffer, 1926), E. fuldensis Lehmann, 1972, E. similis Goetghebuer, 1939, E. clypeata (Thienemann, 1919), E. brevicalcar (Kieffer, 1911), E. devonica (Edwards, 1929), E. minor (Edwards, 1929)/ fittkaui Lehmann, 1972, Heleniella serratosioi Ringe, 1976, Krenosmittia camptophleps (Edwards, 1929), Nanocladius (s.str.) parvulus (Kieffer, 1909), N. (s.str.) rectinervis (Kieffer, 1911), Orthocladius (s.str.) rubicundus (Meigen 1818), O. (Mesorthocladius) frigidus (Zetterstedt 1838), O. (Euorthocladius) ashei Soponis, 1990, O. (E.) rivicola Kieffer, 1911, O. (E.) saxosus (Tokunaga, 1939), Paracricotopus niger (Kieffer 1913), Pseudosmittia Pe1 Langton 1991, Synorthocladius semivirens (Kieffer, 1909), Tvetenia calvescens (Edwards, 1929),Thienemanniella Pe2b Langton 1991, P. (s.str.) laetum (Meigen, 1818), Polypedilum (s.str.) pedestre (Meigen, 1830). Six of the collected taxa were recorded in the Czech Republic for the first time:

\section{SUBFAMILY PODONOMINAE}

\section{Paraboreochlus minutissimus (Strobl, 1895)}

Material examined: 1 pupal exuvia, female

Distribution: A rare species, its findings are up to now limited to small number of countries in West, Central and South Europe, East Palaearctic and Near East and North Africa. It represents the third record of the subfamily Podonominae from the Czech Republic (Bohemia).

Comments: P. minutissimus has been traditionally listed among spring dwellers (Thienemann 1936) and some later findings have confirmed this as well (Lindegaard 1995, Ferrarese 2005). On the other hand, the record from Otava River is further evidence that larvae live in the higher order streams (Schmid-Araya \& Schmid 1995, Janeček \& Moog 1995, Bitušík \& Hamerlík 2001, Hayford 2009). Ferrarese (2005) concluded that the presence of moss is not necessary in the habitat but larvae require some amount of fine organic particles.

$P$. minutissimus is evidently an infrequent species. Only one pupal exuviae was always found amongst hundreds of specimens collected from two streams in Slovakia. Hayford (2009) has supposed that larvae could have inhabited the hyporheic zone of the rivers and this could explain the rare occurrence of the preimaginal stages in samples taken by conventional sampling methods.

\section{SUBFAMILY TANYPODINAE}

\section{Trissopelopia longimanus (Staeger 1839)}

Material examined: 1 praepupa

Distribution: Palaearctic species, recently known mostly from south-western, and partly from central European countries.

Comments: Larvae of $T$. longimanus can be considered to be oligo-stenothermic. They have been found in springs, mountain brooks and also in the littoral of some Scandinavian lakes (Vallenduuk \& Moller Pillot 2007 and citations therein). Larvae live in streams where they prefer mosses even in hygropetric conditions (Fittkau 1962, Lindegaard et al. 1975) but Hildrew et al. (1985) found them mainly between dead leaves on a stream bottom. 


\section{SUBFAMILY DIAMESINAE}

\section{Boreoheptagyia monticola (Serra-Tosio, 1964)}

Material examined: 2 pupal exuviae, females

Distribution: West Palaearctic distribution, known recently from a small number of European countries situated rather in South and Central Europe including Poland and Slovakia.

Comments: Larvae of Boreoheptagyia inhabit rocks and boulders at the splash zone of cool streams where feed on periphyton. B. monticola is a cold-stenothermic species that was found as a member of kryal chironomid community at high altitudes in the Italian Alps (Lencioni et al. 2007). On the other hand, Langton \& Casas (1999) found larvae of B. monticola in Sierra Nevada in permanent streams at $\approx 700 \mathrm{~m}$ a.s.l.

\section{SUBFAMILY ORTHOCLADIINAE}

\section{Cricotopus (Cricotopus) similis Goetghebuer 1921}

Material examined: 2 pupal exuviae, 1 male, 1 female

Distribution: Palaearctic species widely distributed across Europe but has not been recorded in all countries. White spots on the map are most likely due to rather insufficient data than actual absence of the species.

Comments: Rheophilic species, larvae live in brooks and streams with exception of large rivers and mountain brooks (e.g. Gendron \& Laville 1997, Moller Pillot 2013). In Slovakia, pupal exuviae were found in sub-mountain and lowland rivers including polluted sites. It occurs together with other species of the subgenus, especially with $C$. tremulus, C. fuscus, $C$. triannulatus, $C$. bicinctus and $C$. vierriensis but seems to be much less numerous than those species.

\section{Heleniella serratosioi Ringe, 1976}

Material examined: 4 pupal exuviae, 3 males, 1 female

Distribution: Seems to be west Palaearctic species, more or less continuously distributed in west and central Europe, Finland is only northern European country with presence of the species.

Comments: The species is rheophilic and cold-stenothermic with occurrence in springs and rhithral zone of streams. The larvae live on bottom with layers of fine detritus (Moller Pillot 2013 and citation therein). It seems that in Slovakia the species occurs more frequently than $H$. ornaticollis.

\section{Krenosmittia camptophleps (Edwards, 1929)}

Material examined: 12 pupal exuviae, 5 males, 7 females

Distribution: Palaearctic species widely distributed across Europe, however, due to insufficient data there are many white spots on the map of its occurrence.

Comments: Rheophilic and rather cold-stenothermic larvae of the species inhabit depositions of fine detritus in microhabitats with slower current. In comparison with $K$. boreoalpina it seems to be less linked to montane regions and can be find in streams of higher orders (hyporhithral). In Slovakia, both species are frequently found together. Thienemann (1954) found larvae of $K$. camptophleps in terrestrial habitats. 
Acknowledgements: Thanks are due to our colleague Laci Hamerlík for helpful comments and language corrections of the manuscript. This chironomid study was supported by project ITMS 26210120024 "Renewal and development of infrastructure for ecological and environmental research at UMB".

\section{References}

Bitušík P. (1993): New records of chironomids (Diptera. Chironomidae) from Czech Republic and Slovak Republic. - Biologia, Bratislava 48: 189-194.

Bitušík P. \& Hamerlík L. (2001): Chironomids (Diptera: Chironomidae) of the two streams in the Poloniny National Park (East Carpathians, Slovakia). - Acta Universitatis Carolinae Biologica 45:15-18.

Ferrarese U. (2005): Paraboreochlus minutissimus (Strobl, 1894): primo ritrovamento di Podonominae (Diptera: Chironomidae) in Italia. - Studi Trentini di Scienze Naturali, Acta Biologica 81: 139-143.

Fittkau E.J. (1962): Die Tanypodinae (Diptera: Chironomidae) (Die Tribus Anatopyniini, Macropelopiini und Pentaneurini). - Abh. Larvalsyst. Insekten 6: 1-453.

Gendron J.M. \& Laville H. (1997): Chironomidae (Diptera) of the Aude, a Mediterranean river from eastern Pyrenees: Biocoenotical and typological study. - Ann. Limnol. 33: 93-106.

Hayford B. (2009): First records of Podonominae from Outer Mongolia with notes on ecology and biogeographic distribution. - J. Kansas Ent. Soc. 82: 305-310.

Hildrew A.G., Townsend C.R. \& Hasham A. (1985): The predatory Chironomidae of an iron-rich stream: feeding ecology and food web structure. - Ecol. Ent. 10: 403-413.

Janecek B.F.U. \& Moog R. (1995): Diptera, Chironomidae, Podonominae \& Buchonomyiinae, Part III. In Moog O. (ed.), Fauna Aquatica Austriaca. A comprehensive species inventory of Austrian aquatic organisms with ecological notes. - Wasserwirtschaftskataster, Bundesministerium für Land- und Forstwirtschaft, Vienna, pp. 1-5.

Langton P.H. (1991): A key to pupal exuviae of West Palaearctic Chironomidae. Privately published by Langton P.H., 3, St. Felix Road, Ramsey Forty Foot, Huntingdon, Cambridgeshire, England PE17 1YH, 386 pp.

Langton P.H. \& Casas J. (1999): Changes in chironomid assemblage composition in two Mediterranean mountain streams over a period of extreme hydrological conditions. - Hydrobiologia 390: 37-49.

Langton P.H. \& Visser H. (2003): Chironomidae exuviae. A key to pupal exuviae of the West Palaearctic Region. Interactive Identification System for the Europaean Limnofauna (IISEL), World Biodiversity Database, CD-ROM Series.

Lencioni V., Rossaro B. \& Maiolini B. (2007): Alpine chironomid distribution: a mere question of altitude (pp. 165-180). In T. Andersen (ed.): Contributions to the Systematics and Ecology of Aquatic Diptera - A Tribute to Ole A. Sæther, The Caddis Press, Ohio USA, 358 pp.

Lindegaard C. (1995): Chironomidae (Diptera) of European cold springs and factors influencing their distribution. - J. Kansas Ent. Soc., 68, Suppl.: 108-131.

Lindegaard C., Thorup J. \& Bahn M. (1975): The invertebrate fauna of the moss carpet in the Danish spring Ravnkilde and its seasonal, vertical and horizontal distribution. - Arch. Hydrobiol. 75: 109-139.

Moller Pillot H.K.M. (2013): Chironomidae Larvae of the Netherlands and Adjacent Lowlands, Biology and Ecology of the aquatic Orthocladiinae. KNNV Publishing, Zeist, The Netherlands, 312 pp.

Sæther O.A. \& Spies M. (2013): Fauna Europaea: Chironomidae. In Beuk P. \& Pape T. (eds): Fauna Europaea: Diptera, Nematocera. Fauna Europaea version 2.6, http://www.faunaeur.org.

Schmid-Araya J.M. \& Schmid P.E. (1995): The invertebrate species of a gravel stream. - Jber. Biol. Stn Lunz 15: 11-21.

Syrovátka V.\& Langton P.H. (2015): First records of Lasiodiamesa gracilis (Kieffer, 1924), Parochlus kiefferi (Garrett, 1925) and several other Chironomidae from the Czech Republic and Slovakia. - CHIRONOMUS Journal of Chironomidae Research 28: 45-56.

Thienemann A. (1936): Alpine Chironomiden (Ergebnisse von Untersuchungen in der Gegend von Garmisch Partenkirchen). - Arch. Hydrobiol. 30: 167-262.

- (1954): Chironomus. Leben, Verbreitung und Wirtschaftliche Bedeutung der Chironomiden. - Binnengewässer 20: $1-834$.

Vallenduuk H.J. \& Moller Pillot H.K.M. (2007): Chironomidae larvae of the Netherlands and adjacent lowlands. General ecology and Tanypodinae. KNNV Publishing, Zeist, 144 pp.

\section{Niekol'ko nových nálezov pakomárov (Diptera: Chironomidae) z Českej republiky}

Počas výskumu šumavských jazier bola 28. júla 2009 boli odobrané exúviá pakomárov z hladiny rieky Otava asi $3 \mathrm{~km}$ pod sútokom Křemelnej a Vydry $\left(49^{\circ} 08^{\prime} 02.2^{\prime \prime} \mathrm{N}, 13^{\circ} 30^{\prime} 02.4^{\prime \prime} \mathrm{E}\right)$. Vzorka obsahovala 286 exúvií, ktoré boli identifikované do 36 druhov, resp. taxónov. Z nich šest' bolo zaznamenaných na území Českej republiky po 
prvýkrát: Paraboreochlus minutissimus (Strobl, 1894), Trissopelopia longimanus (Staeger 1839), Boreoheptagyia monticola (Serra-Tosio, 1964), Cricotopus (s.str.) similis Goetghebuer 1921, Heleniella serratosioi Ringe, 1976 a Krenosmittia camptophleps (Edwards, 1929). Prehl'ad druhov je doplnený informáciami o ich súčasnom rozšírení a ekologických nárokoch.

Authors' addresses: Peter Bitušík and Katarína Trnková, Dept. Biology and Ecology, Faculty of Science, Matthias Belius University, SK-97401 Banská Bystrica, Slovakia.

E-mail: peter.bitusik@umb.sk 